\title{
Virulence determinants of Escherichia coli 06 extraintestinal isolates analysed by Southern hybridizations and DNA long range mapping techniques
}

\author{
Gabriele Blum, ${ }^{1}$ Manfred Ott, ${ }^{1}$ Alan Cross $^{2}$ and Jörg Hacker ${ }^{1 *}$ \\ $1 /$ Institut für Genetik und Mikrobiologie, University of Würzburg, Röntgenring 11. \\ W-8700 Würzburg, Germany and ${ }^{2}$ Walter Reed U.S. Army Institute of Research, \\ Walter Reed Medical Center, Washington, D.C. 20307-5100, U.S.A.
}

(Received July, 30, 1990; accepted in revised form October 24, 1990)

Blum, G. (Institut für Genetik und Mikrobiologie, University of Würzburg, Röntgenring 11, W-8700 Würzburg, Germany), M. Ott, A. Cross and J. Hacker. Microbial Pathogenesis 1991; 10: 127-136.

A total of 16 Escherichia coli 06 strains isolated from cases of extraintestinal infections were analysed for the genetic presence and phenotypic expression of fimbrial adhesins ( $P, S / F I C$, type (), aerobactin and hemolysin. In addition restriction fragment length polymorphisms (RFLPs) of Xbal-cleaved genomic DNA of seven selected strains, separated by orthogonal field alternation gel electrophoresis (OFAGE) were determined and virulence-associated DNA probes were used for Southern hybridization studies of the $X b a l$-cleaved genomic DNAs. The virulence characteristics and hybridization patterns obtained differed between the various isolates. In three isolates hemolysin genes and $P$ fimbrial determinants were located on the same $X b a l$ fragments. Furthermore, multiple copies of FIC determinants (foc) could be detected in two strains. Our data show that the new technique of pulse field electrophoresis together with Southern hybridization represents a powerful tool for the genetic analysis of pathogenic bacteria.

Key words: E. coli serotype 06; extraintestinal isolates; virulence factors; gene probes; DNA long range mapping; epidemiology.

\section{Introduction}

Escherichia coli strains are frequently found as the etiological agents of urinary tract infections (UTI) and, to a minor extent of sepsis and newborn meningitis (NBM). ${ }^{1}$ Various factors contribute to the virulence of these extraintestinal $E$. coli strains. Hemolysin production, expression of different adhesins and the synthesis of iron uptake substances such as aerobactin, as well as the $O$ and $K$ surface antigens are important for the extraintestinal pathogenicity of $E$. coli..$^{2-6}$

Fimbrial adhesins can be distinguished by differences in receptor specificities, which are detectable in vitro by the use of different target cells in agglutination assays. ${ }^{7}$ Type I fimbriae recognize mannose residues present e.g. On Saccharomyces cerevisiae cells. ${ }^{8}$ $P$ fimbrial adhesins mediating adhesion to galactose-galactoside structures can be determined by using blood group $P$ erythrocytes. ${ }^{9}$ The $S$ fimbrial adhesin phenotype

-Author to whom correspondence should be addressed. 
Table 1 Virulence patterns of $E$. coli 06 strains

\begin{tabular}{|c|c|c|c|c|c|c|c|c|c|c|c|c|}
\hline \multirow[b]{2}{*}{ No. } & \multirow[b]{2}{*}{ Strain } & \multirow[b]{2}{*}{ Serotype } & \multicolumn{4}{|c|}{ Adhesins } & \multirow[b]{2}{*}{ Fim } & \multirow[b]{2}{*}{ fim } & \multicolumn{2}{|c|}{ Aerobactin } & \multicolumn{2}{|c|}{ Hemolysin } \\
\hline & & & $P$ & $\begin{array}{c}\text { pap/ } \\
\text { prs }\end{array}$ & Sfa & $\begin{array}{l}\text { sfal } \\
\text { foc }\end{array}$ & & & Aer & aer & Hly & $h / y$ \\
\hline 1 & E351 & $06: K 45$ & - & - & - & - & - & + & + & + & - & - \\
\hline 2 & E817 & $06: \mathrm{K} 2$ & - & + & + & + & - & + & - & - & + & + \\
\hline 3 & 536 & $06: K 15$ & - & + & + & + & + & + & - & - & + & + \\
\hline 4 & E642 & $06: K 15$ & - & + & - & + & - & + & - & - & + & + \\
\hline 5 & ET24 & $06: \mathrm{K5}$ & - & - & - & + & + & + & + & + & - & - \\
\hline 6 & E247 & $06: K 15$ & - & + & - & + & + & + & - & - & + & + \\
\hline 7 & E457 & $06: k 5$ & - & - & - & - & - & + & + & + & - & - \\
\hline 8 & C438 & $06: K+$ & - & - & - & + & - & + & - & - & + & + \\
\hline 9 & C294 & $06: K+$ & + & + & - & + & - & + & + & + & + & + \\
\hline 10 & C410 & $06: K+$ & - & - & - & + & - & + & + & + & - & - \\
\hline 11 & C502 & $06: K+$ & + & + & + & + & + & + & - & - & + & + \\
\hline 12 & C504 & $06: K+$ & - & - & - & + & - & + & - & - & + & + \\
\hline 13 & C499 & $06: K+$ & - & - & - & - & + & + & - & - & - & - \\
\hline 14 & C5660 & $06: K+$ & + & + & - & + & - & + & + & + & + & + \\
\hline 15 & C398 & $06: K+$ & - & - & + & + & + & + & - & - & + & + \\
\hline 16 & IH3095 & $06: K+$ & - & + & + & + & + & + & - & - & - & - \\
\hline \multicolumn{3}{|c|}{$\%$ positive } & 19 & 50 & 31 & 85 & 44 & 100 & 37 & 37 & 62 & 62 \\
\hline
\end{tabular}

is a result of the recognition of sialic acid-galactoside containing receptors. ${ }^{10,11}$ The genetically related FIC fimbriae do not exhibit any agglutination activity with red blood cells. ${ }^{12-14}$ Hemolysis and aerobactin synthesis can easily be evaluated using blood agar plates ${ }^{6}$ and a bioassay for iron uptake, respectively. ${ }^{15}$ In the last decade the genetic determinants coding for adhesins, hemolysin and aerobactin have been cloned and DNA probes have been developed to detect the corresponding gene clusters. ${ }^{6.9,13,16-18}$ To determine the virulence patterns of particular strains, phenotypic characterization of virulence factors and DNA-DNA dot blots with virulence associated gene probes were carried out. The new method of pulse field electrophoresis ${ }^{19-21}$ allows the comparison of restriction fragment length polymorphisms of strains following digestion of DNA with rare cutting enzymes. Using Southern hybridization studies certain virulence determinants could be assigned to particular DNA fragments. As a first approach, in this study we used orthogonal field alternation gel electrophoresis (OFAGE) in combination with DNA-DNA-hybridization with virulence-associated gene probes to analyse the virulence pattern and the genome structure of extraintestinal $E$. coli strains of the serogroup 06 . Our data show that the 06 strains analysed represent a heterogeneous group of clinical isolates with individual virulence features and differences in genomic structures.

\section{Results}

Virulence patterns of $16 \mathrm{E}$. coli 06 strains

Sixteen E. coti 06 strains were characterized phenotypically according to the production of adhesins ( $P, S$, type 1$)$, hemolysin and aerobactin. From Table 1, it can be seen, that $P$ adhesins are rather rare (19\%), whereas 31 and $44 \%$ of the strains express $S$ fimbrial adhesins and Type I fimbriae, respectively. Nearly one third of the strains 

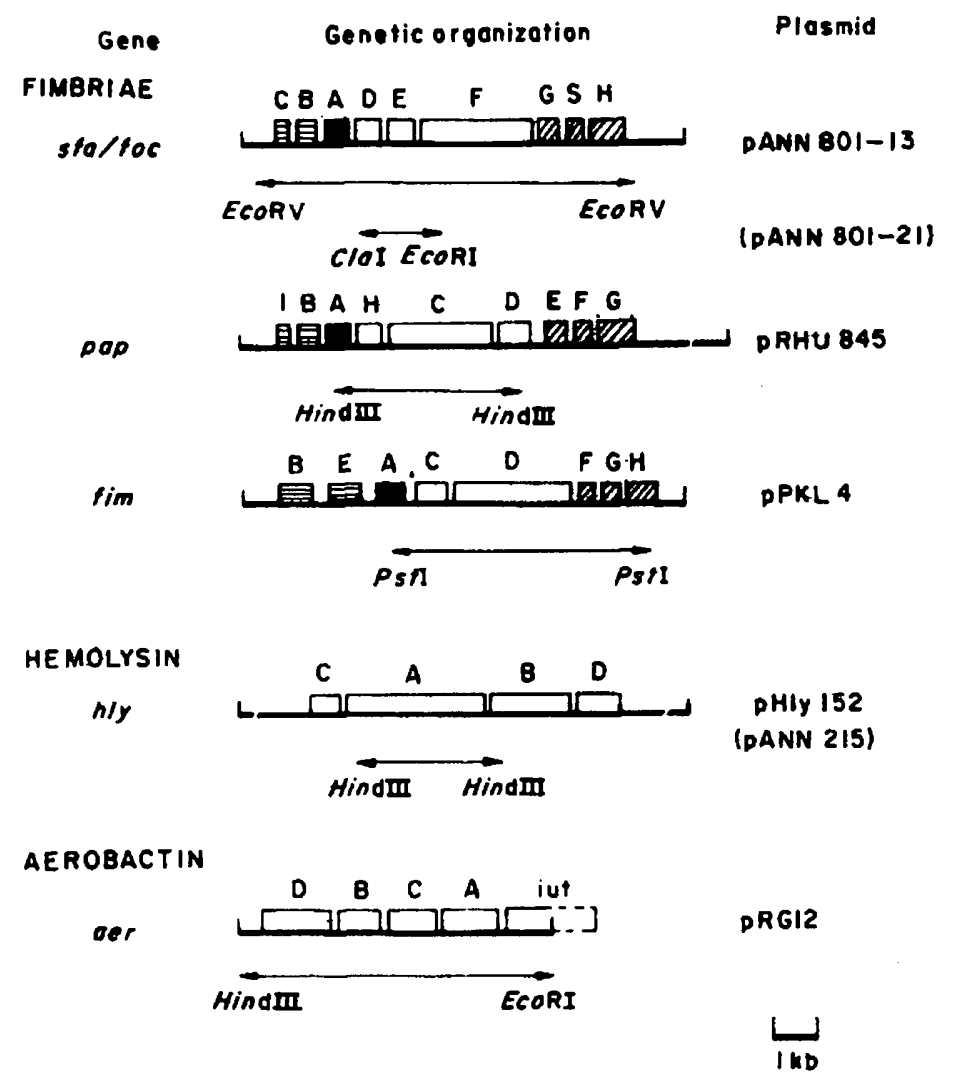

Fig. 1. Genetic organization of virulence determinants (cistrons are given as boxes, designated by capital letters) and derived gene probes (given as horizontal arrows with restriction enzyme cleavage sites). The determinants encoding fimbriae (sfa/foc, pap. fim), hemolysin ( $h / y)$, and aerobactin (aer) are shown. Plasmids used for the generation of DNA probes are indicated on the right side. In the case of fimbrial determinants, cistrons belonging to analogous functional regions are styled in the same way (目, regulation, $\square$, major fimbrial subunit; $\square$, transport and biogenesis; adhesion and minor fimbrial subunits).

produced aerobactin and two thirds exhibited a hemolytic phenotype. In addition, DNA-DNA dot blots were performed using five virulence-associated gene probes specific for the three adhesins, aerobactin and hemolysin (Fig. 1). As also indicated in Table 1 in the case of aerobactin and hemolysin producing strains, the phenotype is in total agreement with the genotype. In contrast the incidence of adhesin positive strains is higher when determined by DNA-hybridization than by phenotypic characterization.

\section{Analysis of restriction fragment length polymorphism (RFLP) by orthogonal field alternation gel electrophoresis (OFAGE)}

For further analysis, genomic DNAs of seven selected strains were isolated and cleaved with $X$ bal, a rare cutting enzyme for $E$. coli DNA. By means of OFAGE RFLPs could be detected [Fig. 2(a)]. It is evident that the restriction patterns are very different, arguing for genetic diversity. An interpretation scheme of the Xbal patterns of strains is given in Fig. 3.

\section{DNA long-range mapping with virulence associated gene probes}

The virulence-associated DNA probes (see Fig. 1) were further used in Southern hybridization studies of Xbal-cleaved genomic DNA of seven $E$. coli 06 strains (cf. 
(a)

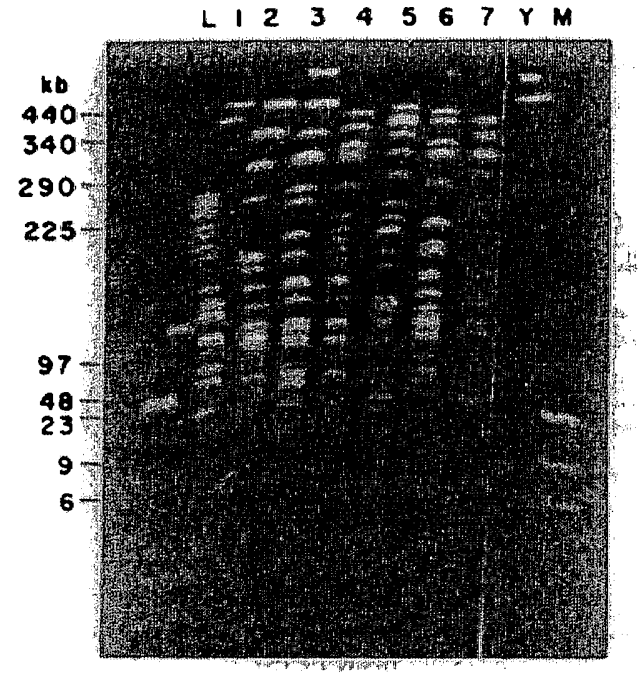

(c)

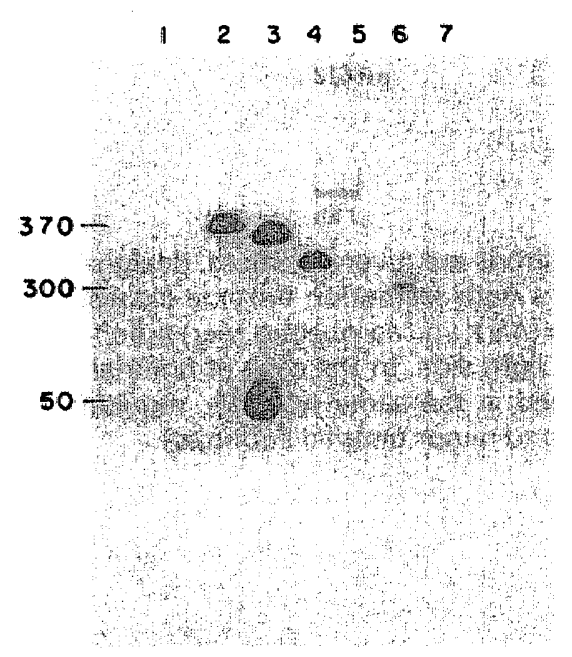

(e)

1234567

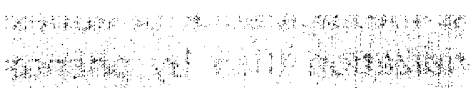

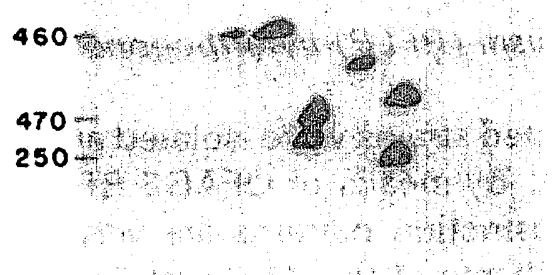

(b)

1234567

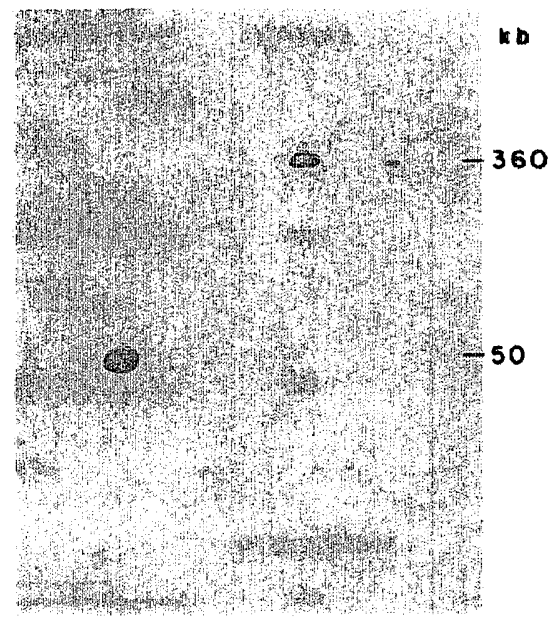

(d)

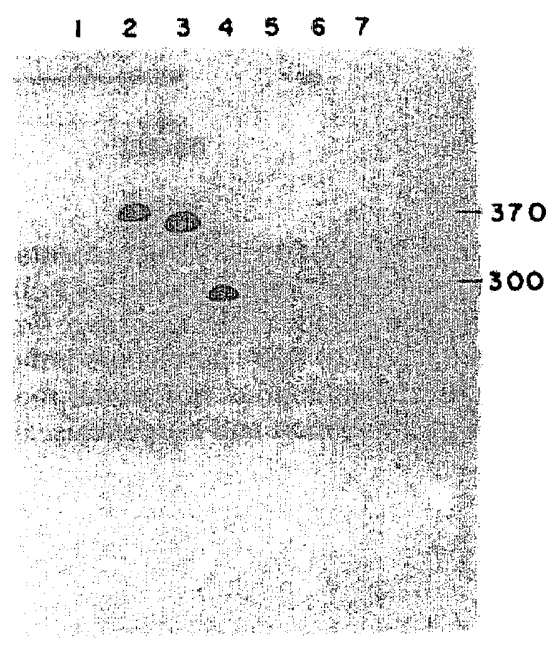

(f)

1234567
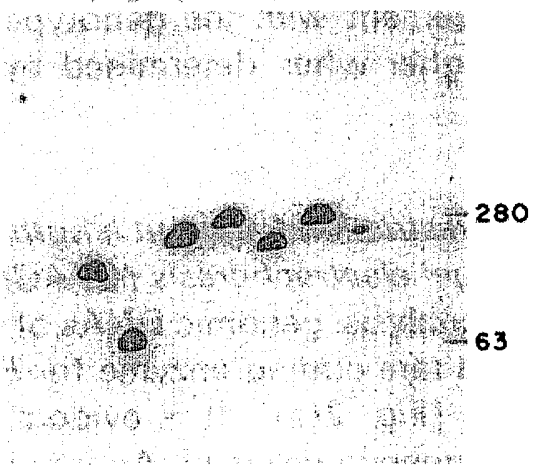

Fig. 2. Orthogonal field alternation gel electrophoresis (OFAGE) analysis of Xbal cleaved genomic DNAs (a) and Southern hybridization using aer (b), hly (c), pap (d), sfa/foc (e), and fim (f) specific gene probes (cf. Fig. 1). Lambda concatemers (L), yeast chromosomes ( $Y$ ), and Hindill cleaved lambda DNA (M) were used as DNA size markers. DNA sizes are indicated. Escherichia coli strains are as follows: lane 1, E 351; lane 2, E 817; lane 3, 536; lane 4, E 642; lane 5, ET 24; lane 6, E 247; lane 7, E 457. 


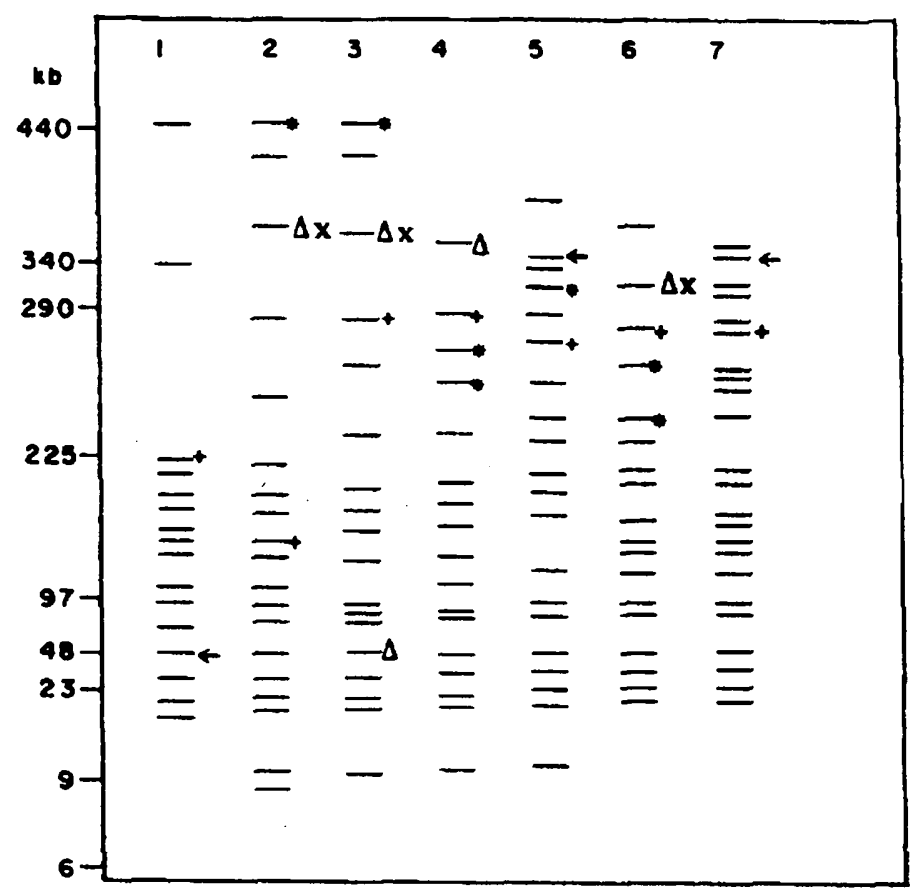

Fig. 3. Interpretation scheme of $X$ bal patterns hybridized to DNA probes (cf. Figs 1 and 2). Strains are as follows: lane 1, E 351 ; lane 2, E 817; lane 3, 536; lane 4, E 642; lane 5, ET 24 ; lane 6. E 247; lane 7, E 457. Abbreviation for hybridization to DNA probes is as follows : $\leftarrow$ aer, $\Delta h / y, \times$ pap, ${ }^{*}$ sfalfoc, + fim.

Table 1) separated by the OFAGE technique [Fig. 2(b-f)]. In nearly all strains the virulence determinants of a certain type are situated on fragments of different size. With regard to the use of $h / y$ and pap specific DNA probes, some strains display hybridization in the same fragments [Fig. 2(c) and (d), lanes 2, 3 and 6], which may suggest a physical linkage of these virulence determinants. With the exception of strains 536 [Fig. 2(c), lane 3], E642, and E247 [Fig. 2(e) lanes 4 and 6], only one DNA fragment hybridized to the respective DNA probes. It has been shown previously, that strain 536 carries two $h / y$ determinants, represented by the two DNA fragments which hybridize with the $h / y$-specific probe. ${ }^{22}$ Strains E642 and E247 show a multiple hybridization with the $s f a / f o c$ specific gene probe. Since this hybridization might indicate the presence of more than one copy of the adhesin specific gene clusters in the genome of these strains, the corresponding DNAs were analysed further (see below).

Copy number of FIC determinants (foc)

Strains E642 and E247 do not exhibit any S-specific hemagglutination (Table 1), therefore the occurrence of multiple signals following hybridization with a sfa/foc specific gene probe may indicate the presence of more than one FIC determinant on the chromosomes of these particular strains. To ensure the copy number of foc determinants in the genome of strains E642 and E247 further DNA long range mapping using two other rare cutting enzymes was performed (Fig. 4). Sfil (lanes 1 and 3) and Notl (lanes 2 and 4) cleaved genomic DNA of the strains E247 (lanes 1 and 2) and E642 (lanes 3 and 4) were hybridized to the $1.8 \mathrm{~kb}$ EcoRI-Clal sfa/foc specific DNA probe (cf. Fig. 1). In the case of the Sfil digestion, two fragments appeared in both strains. Following Notl cleavage strain E247 also exhibits two fragments, whereas strain E642 displays three fragments using the sfa/foc specific DNA probe. As the 

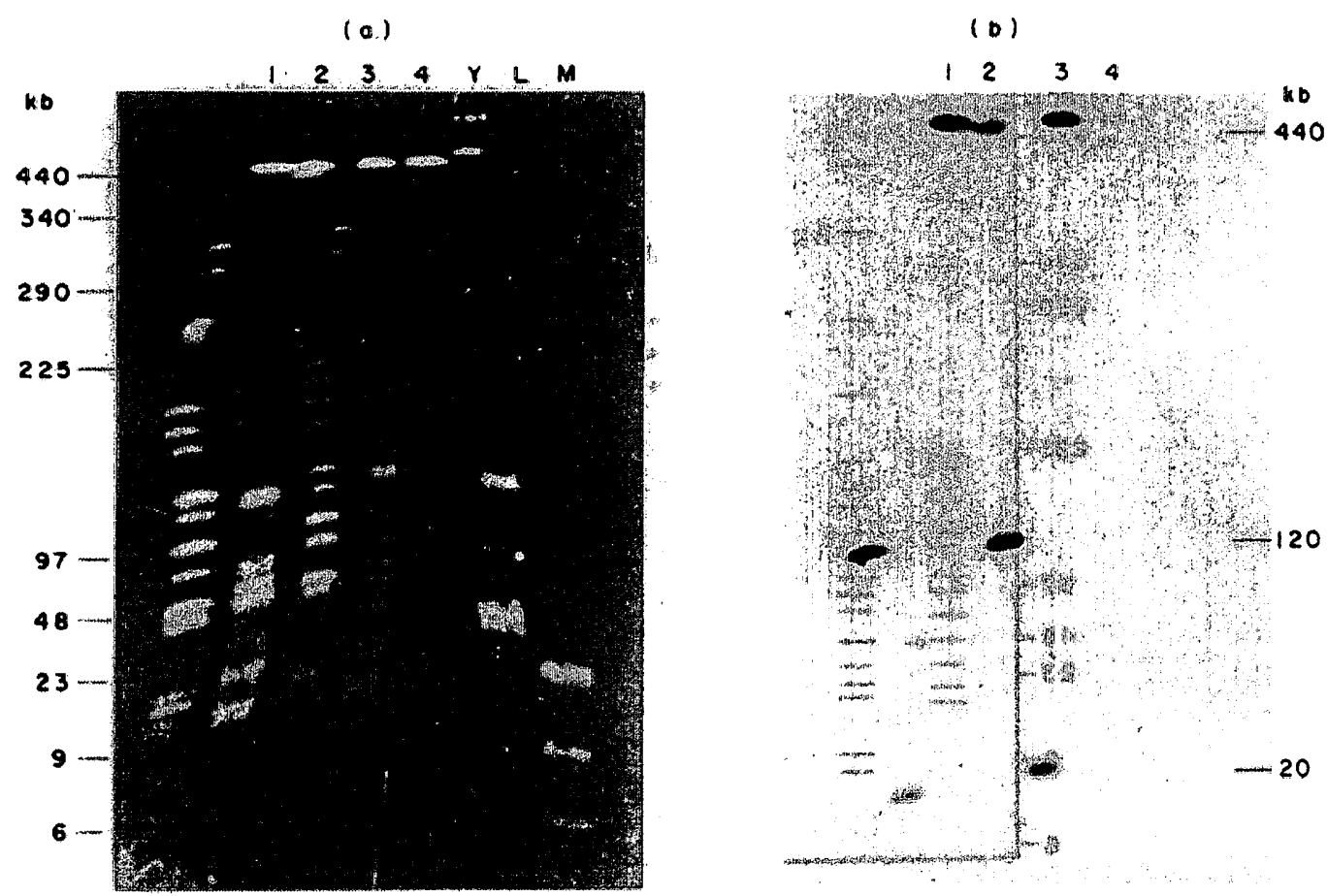

Fig. 4. (a) Orthogonal field alternation gel elecrophoresis of Sfil (lanes 1 and 3) and Notl (lanes 2 and 4) cleaved genomic DNAs of strains E 247 (lanes 1 and 2) and E 642 (lanes 3 and 4). (b) Southern hybridization using the sfa/foc specific DNA probe derived from plasmid pANN 801-21 (cf. Fig. 1). DNA sizes are indicated. Yeast chromosomes $(Y)$, lambda concatemers $(L)$ and the HindIII fragments of lambda DNA $(M)$, were used as size markers.

cloned foc and sfa determinants contain no Xbal, Sfil, and Notl cleavage sites (data not shown), these data strongly argue for the presence of more than one copy of foc determinants in the genomes of these $E$. coli 06 strains.

\section{Discussion and conclusions}

In this report the virulence patterns of $16 \mathrm{E}$. coli 06 extraintestinal isolates were analysed. The various isolates differ in the expression of adherence factors, and the genetic presence of the corresponding determinants. This could be due to the presence of silent genes not expressed under laboratory conditions. Several studies within the last years have reported particular environmental prerequisites necessary to obtain optimal expression of certain virulence traits. ${ }^{23,24}$ Furthermore, especially in the case of $P$ adhesins it has been demonstrated that a shift of receptor specificity alters phenotypic detection by hemagglutination. ${ }^{9}$

Seven strains were selected, for DNA long-range mapping analysis. Xbal-cleaved genomic DNAs, separated by the OFAGE technique, displayed a marked RFLP. Southern hybridization experiments using the virulence associated DNA probes revealed that in nearly all cases the corresponding determinants were situated on DNA fragments of dissimilar size (Fig. 3 ). In some strains, the determinants, encoding $P$ adhesins and hemolysin were located on the same DNA fragments, arguing for a physical linkage of these traits. Genetic linkage of $h / y$ and $P$ fimbriae determinants has already been demonstrated for the $E$. coli 06 strain $536,{ }^{22}$ as well as for other strains not belonging to serogroup $06 .^{25-27}$

In two strains, multiple copies of FIC determinants could be detected. Until now, the presence of more than one copy of the $P$ adhesin determinants had been shown on the genome of $E$. coli strains. ${ }^{9.27 .28}$ In general, duplications of adhesin determinants 
seem to be advantageous for isolates because they offer the possibility for a selection of new binding specificities. In addition, the generation of serological variants of adhesins which express unique recognition properties may depend on such gene duplications. It has already been shown that the expression of different adherence properties by one $E$. coli strain is a prerequisite for full virulence in vivo. ${ }^{29.30}$ The existence of multiple copies of adhesin determinants on the chromosome of particular isolates were also demonstrated for pili and opacity proteins of Neisseria gonorrhoeae. ${ }^{31,32}$ Furthermore, duplications have been described for hemolysin determinants of E. coli ${ }^{33,34}$ (see Fig. 2) and Vibrio parahaemolyticus ${ }^{35}$ and for the cholera toxin gene $(c t x) .^{36}$

From the data presented here, it is apparent that the $E$. coli 06 strains investigated, although all of the same $\mathrm{O}$-serotype, exhibit a heterogeneous picture according to the virulence pattern and restriction fragment pattern obtained by DNA long-range mapping which is consistent with data obtained recently. ${ }^{37.38}$ Until now, epidemiological studies were mainly based on the outer membrane profile and analysis of the electrophoretic types of alleloenzymes. ${ }^{39.40}$ Here, we introduce the method of DNA long range mapping as a tool for evaluation of genetic relatedness and for epidemiological investigations.

\section{Materials and methods}

Bacterial strains and plasmids. Escherichia coli strains E817 and E247 are isolates from the spinal fluid of neonates; E642, E351 and E457 are blood isolates. These strains were isolated at the Walter-Reed Army Hospital. Strain $\mathbf{5 3 6}$ was isolated from a case of pyelonephritis, the other strains were isolates from patients with cystitis. Strain $\mathrm{IH} 3095$ is a gift from T. K. Korhonen. The other strains were isolated at the University of Würzburg. Plasmids used as source for DNA probes are depicted in Fig. 1. As a host strain for recombinant DNA, E. coli K-12 strain HB101 was used. ${ }^{41}$ Cultivation was carried out under antibiotic pressure: concentrations were as follows: ampicillin $(50 \mu \mathrm{g} / \mathrm{ml})$, chloramphenicol $(20 \mu \mathrm{g} / \mathrm{ml})$, and tetracycline $(15 \mu \mathrm{g} / \mathrm{ml})$.

Media, chemicals and enzymes. Bacteria were grown either in Luria Bertani (LB) broth or on LB-agar or CFA-agar. Radiochemicals were purchased from Amersham-Buchler, Germany. Antibiotics were a gift from Bayer, Germany. All other chemicals were obtained from Sigma, Germany. Restriction enzymes were purchased from Gibco, Germany.

Determination of adhesins. The presence of adhesins was determined by hemagglutination (HA) assays using human and bovine erythrocyte suspensions with and without $2 \%$ mannose as described. ${ }^{7.9 .10}$ The erythrocytes were obtained locally. P-specific adherence was detected by agglutination using human PI erythrocytes and Gal-Gal-coated latex beads obtained from KabiVitrum (Sweden) ${ }^{9,26}$. S-specific binding was assayed in a HA-test using bovine erythrocytes treated with neuraminidase as described previously. "Type I adhesins were detected by mannose sensitive adherence of strains with Saccharomyces cerevisiae cells. ${ }^{7.8}$

Hemolysin production. Erythrocyte lysis was detected on meat agar plates containing washed human erythrocytes, or in a liquid assay. ${ }^{6}$

Aerobactin bioassay. The aerobactin cross-feeding bioassay was carried out by a modification of the test described previously by Braun et al. ${ }^{15}$ Briefly, $10^{9}$ cells of the aerobactin-requiring indicator strain E. coli K-12 EN99 were cultivated in M9-soft agar containing $200 \mathrm{mM}$ of the iron chelator substance 2'2' dipyridyl (Sigma, Germany). For analysis, supernatants of strains were dropped on filter discs and incubated overnight on the EN99-containing soft agar plates under iron-restricted conditions. Production of aerobactin by the test strains was indicated by a zone of enhanced growth of EN99 around the discs with the supernatants of the test strains.

DNA techniques. Chromosomal DNA was isolated as described by Knapp et al..$^{33}$ Plasmid DNA was isolated by the clear lysate method and purified over $\mathrm{CsCl}$ gradients. ${ }^{42.43}$ DNA fragments were recovered from agarose gels by the freeze squeeze method. ${ }^{44}$ For cleavage, 
DNA was treated with restriction enzymes under appropriate conditions and electrophoresed in $1 \%$ agarose gels. ${ }^{43}$ As DNA size marker the Hindlll fragments of lambda DNA were used.

Orthogonal field alternation gel electrophoresis (OFAGE). Chromosomal DNA for OFAGE analysis was isolated as described by Grothues and Tümmler. ${ }^{20}$ Agarose blocks containing genomic DNA were equilibrated in restriction enzyme buffer for $3 \mathrm{~h}$ on ice and cleaved in fresh buffer with 30 units restriction enzyme for $3 \mathrm{~h}$ at the appropriate incubation temperature. Orthogonal field alternation gel electrophoresis was performed with a Consort pulse field system, which includes a computer equipped E 654 power supply and a submarine basin (Consort, Belgium), using $1 \%$ agarose gels in $0.25 \times$ TBE buffer. Constant voltage of $250 \mathrm{~V}$ for $72 \mathrm{~h}$ was applied. The electric fields, which were arranged at a $120^{\circ}$ angle, alternated every $20 \mathrm{~s}$. As DNA size markers lambda ladders (Pharmacia, Germany) and the chromosomes of Saccharomyces cerevisiae WAY 5-4A (Biometra, Germany), were used.

Gene probes and radioactive labelling. The gene probes used are depicted in Fig. 1. After recovering from agarose gels ${ }^{44}$ the DNA fragments were radioactively labelled by the method of Feinberg and Vogelstein ${ }^{45}$ with a random priming kit, purchased from Boehringer, Germany.

As pap specific probe a HindIII fragment of $4.8 \mathrm{~kb}$, isolated from the plasmid pRHU845 (Tc') was used ${ }^{26}$ As shown previously, this probe is also specific for the prs gene cluster coding for $P$ related adhesins. ${ }^{9}$ As sfa/foc specific DNA probe, a Clal-EcoRI fragment of $1.8 \mathrm{~kb}$ from the recombinant DNA pANN801-13 (Ap') was used. " This fragment was also subcloned into pBR322, thereby resulting in the plasmid pANN801-21 (Ap'). Using this probe, foc specific sequences which code for FIC fimbriae can also be detected. ${ }^{13}$ For differentiation of sfa and foc gene clusters the $9 \mathrm{~kb}$ EcoRV fragment of pANN 801-13 was used as DNA probe in Southern hybridization experiments. ${ }^{13}$ As specific DNA probe for type 1 fimbriae gene clusters the $6.0 \mathrm{~kb}$ Pstl fragment of plasmid pPKL4 $\left(A p^{\prime}\right)$ was used ${ }^{46}$ As aerobactin specific probe a $7.0 \mathrm{~kb}$ HindIII-EcoRI fragment of plasmid pRG12 (Ap') was used. ${ }^{16}$ The $3.2 \mathrm{~kb}$ Hindlll fragment which represents the insert DNA of plasmid pANN215 $\left(\mathrm{Cm}^{\prime}\right)$ was used as $h / y$ specific probe. Plasmid pANN215 is derived from the wild-type plasmid pHly152. ${ }^{47}$

Colony-dot-hybridization. For rapid detection of the presence of specific virulence factors in genomes of strains, the colony dot hybridization procedure was used, as described by Maniatis et $a l^{43}$.

Southern hybridization. The transfer of DNA from agarose gels to nitrocellulose paper and the washing and autoradiography of the filters was performed as described previously. ${ }^{48}$ The filters were hybridized in $50 \%$ formamide for $24 \mathrm{~h}$ at $42^{\circ} \mathrm{C}$. For rehybridization of Southern blot filters, they were incubated for $10 \mathrm{~min}$ in $1 \mathrm{mM}$ EDTA, pH 7.5 at $100^{\circ} \mathrm{C}$. Complete removal of the DNA probe was controlled by autoradiography of the nitrocellulose filter for at least 3 days, and the filter could then be used for a second hybridization.

The authors wish to thank $M$. Schmittroth (Würzburg) for excellent technical assistance, Dr $M$. Wuenscher (Würzburg) for critical reading of the manuscript, Dr T. K. Korhonen (Helsinki) for sending strain IH3095, and $\mathrm{H}$. Kurz (Würzburg) for help in preparing the manuscript. The work was supported by the Deutsche Forschungsgemeinschaft (DFG Ha 1434/1-7) and the Fond der Chemischen Industrie.

\section{References}

1. Orskov I, Orskov F. Escherichia coli in extraintestinal infections. J Hyg Camb 1985; 95: 551-75.

2. Svanborg-Eden C, de Man P. Bacterial virulence in urinary tract infection. Infect Dis Clin N Am 1987; 1: $731-50$.

3. Achtman M, Pluschke G, Clonal analysis of descent and virulence among selected Escherichia coli. Annu Rev Microbiol 1986; 40: 185-210.

4. Achtman M, Mercer A, Kusecek B et al. Six wide spread bacterial clones among Escherichia coli KI isolates. Infect Immun 1983; 39: 315-35.

5. Korhonen TK, Valtonen MV, Parkkinen I et al. Serotypes, hemolysin production and receptor recognition of Escherichia coli strains associated with neonatal sepsis and meningitis. Infect Immun 1985; 48: 48691.

6. Hacker J, Hughes C, Hof H, Goebel W. Cloned hemolysin genes from Escherichia coli that cause urinary tract infections determine different levels of toxicity in mice. Infect Immun 1983; 42: 57-63.

7. Orskov 1, Orskov F. Serology of Escherichia coli fimbriae. Prog Allergy 1983; 33: 80-105. 
8. Korhonen TK. Yeast cell agglutination by purified enterobacterial pili. FEMS Microbiol Lett 1979; 6 : 421-5.

9. Lund B, Marklund B-J, Strömberg N, Lindberg F, Karlsson K-A, Normark S. Uropathogenic Escherichia coli can express serologically identical pili of different receptor specificities. Mol Microbiol 1988; 2 : 155-63.

10. Parkkinen J, Rogers GN, Korhonen T, Dahr W. Finne J. Identification of the O-linked sialyloligosaccharides of glycophorin as the erythrocyte receptors for S-fimbriated Escherichia coli. Infect Immun 1986; 54: 37-42.

11. Hacker J. Schmidt G, Hughes C, Knapp S, Marget M, Goebel W. Cloning and characterization of genes involved in the production of mannose-resistant, neuraminidase-susceptible (X) fimbriae from a uropathogenic 06:K15:H31 Escherichia coli strain. Infect Immun 1985; 47: 434-40.

12. Van Die I, van Jetten R, Hoekstra W. Bergmans H. Type IC fimbriae of a uropathogenic Escherichia coli strain: cloning and characterization of the genes involved in the expression of the subunit gene. Gene 1985; 34: 187-96.

13. Ott M, Hoschützky H, Jann K, van Die I, Hacker J. Gene clusters for S fimbrial adhesin (sfa) and FIC fimbriae (foc) of Escherichia coli: comparative aspects of structure and function. J Bacteriol 1988; 170: 3983-90.

14. Marre R, Kreft B, Hacker J. Genetically engineered S- and FIC-fimbriae differ in their contribution to adherence of Escherichia coli to cultured renal tubulus cells. Infect Immun 1990; 58: 3434-7.

15. Braun V. Gross R, Köster W, Zimmermann L. Plasmid and chromosomal mutants in the iron (III)aerobactin transport system of Escherichia coli. Use of Streptonigrin for selection. Mol Gen Genet 1983; 192: 131-9.

16. Gross R, Engelbrecht $F$, Braun V. Identification of the genes and their polypeptide products responsible for aerobactin synthesis by pColV plasmids. Mol Gen Genet 1985; 201: 204-12.

17. Orskov I, Williams PH, Svanborg-Eden C, Orskov F. Assessment of biological and colony hybridization assays for detection of the aerobactin system in Escherichia coli from urinary tract infections. Med Microbiol Immunol 1989; 178: 143-8.

18. Ekbäck G, Mörner S, Lund B, Normark S. Correlation of genes in the pap cluster to expression of globoside-specific adhesion by uropathogenic Escherichia coli. FEMS Microbiol Lett 1986; 34: 355-60.

19. Lai E, Birren BW, Clark SM, Simon MI, Hood L. Pulsed field gel electrophoresis. Biotechniques 1989; 7: 34-42.

20. Grothues D, Tümmler B. Genome analysis of Pseudomonas aeruginosa by fieldinversion gelelectrophoresis. FEMS Microbiol Lett 1987; 48: 419-22.

21. Lee JJ, Smith HD. Sizing of the Haemophilus influenzae Rd genome by pulsed-field agarose gel electrophoresis. J. Bacteriol 1988; 179: 4402-5.

22. Hacker J, Bender L, Ott $M$ et al. Deletions of chromosomal regions coding for fimbriae and hemolysins occur in vitro and in vivo in various extraintestinal Escherichia coli isolates. Microbial Pathogenesis 1990; 8: 213-25.

23. Schmoll $T$, Ott $M$, Oudega $B$, Hacker J. Use of a wild-type gene fusion to determine the influence of environmental conditions on expression of the $\mathrm{S}$ fimbrial adhesin in an Escherichia coli pathogen. J Bacteriol 1990; 172: 5103-11.

24. Miller JF, Mekalanos JJ, Falkow S. Coordinate regulation and sensory transduction in the control of bacterial virulence. Science 1989; 243: 916-22.

25. Hull SI, Bieler S, Hull RA. Restriction fragment length polymorphism and multiple copies of DNA sequences homologous with probes for $P$ fimbriae and hemolysin genes among uropathogenic Escherichia coli. Can J Microbiol 1988; 34: 307-11.

26. Low D, David V, Lark D, Schoolnik G, Falkow S. Gene clusters governing the production of hemolysin and mannose-resistant hemagglutination are closely linked in Escherichia coli serotype 04 and 06 isolates from urinary tract infections. Infect Immun 1984; 43: 353-8.

27. High NJ, Hales BA, Jann K, Boulnois GJ. A block of urovirulence genes encoding multiple fimbriae

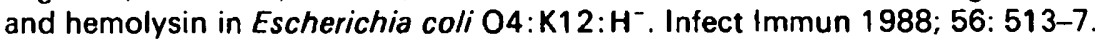

28. Hull S, Clegg S, Svanborg-Eden C, Hull R. Multiple forms of genes in pyelonephritogenic Escherichia coli encoding adhesins binding globoseries glycolipid receptors. Infect Immun 1985; 47: 80-3.

29. Hacker J. Schmoll T, Ott $M$ et al. Genetic structure and expression of virulence determinants from strains of Escherichia coli. In: Kass E, Svanborg-Eden C, eds. Host-parasite interactions in urinary tract infections. Studies in infectious disease research. Chicago: University of Chicago Press, 1989; 144-56.

30. Marre R, Hacker J. Role of S- and common type I-fimbriae of Escherichia coli in experimental upper and lower urinary tract infection. Microbial Pathogenesis 1987; 2: 223-6.

31. Gibbs C, Haas R, Meyer TF. Structural and functional modulation of gonococcal surface proteins. Microbial Pathogenesis 1988; 4: 393-9.

32. Meyer TF, van Putten JPM. Genetic mechanisms and biological implications of phase variation in pathogenic Neisseriae. Clin Microbiol Rev 1989; 2: 5139-45.

33. Knapp S, Hacker J, Jarchau T, Goebel W. Large, instable inserts in the chromosome affect virulence properties of uropathogenic Escherichia coli 06 strain 536. J Bacteriol 1986; 168: 22-30.

34. Hull SI. Hull RA. Linkage and duplication of copies of genes encoding P fimbriae and hemolysin in the chromosome of a uropathogenic Escherichia coli isolate. In: Kass E, Svanborg-Eden C, eds. Hostparasite interactions in urinary tract infections. Studies in infectious disease research. Chicago: University of Chicago Press, 1989; 159-63. 
35. Nishibuchi $M$, Kaper JB. Duplication and variation of the thermostable direct hemolysin (tdh) gene in Vibrio parahaemolyticus. Mol Microbiol 1990; 4: 87-99.

36. Mekalanos JJ. Duplication and amplification of toxin genes in Vibrio cholerae. Cell 1983; 35: $253-63$

37. Zingler G, Schmidt G, Orskov I, Orskov F, Falkenhagen U, Naumann G. K-Antigen indentification, hemolysin production, and hemagglutination types of Escherichia coli 06 strains isolated from patients with urinary tract infections. Zbl Bakt 1990; 274: 372-81.

38. Pere $A$, Leinonen $M$, Väisänen-Rhen V, Rhen $M$, Korhonen TK. Occurrence of Type-IC fimbriae on Escherichia coli strains isolated from human extraintestinal infections. J Gen Microbiol 1985; 131 : 1705-11.

39. Selander RK, Caugant DA, Whittam TS. Genetic structure and variation in natural populations of Escherichia coli. In: Neidhardt FC, ed. Escherichia coli and Salmonella typhimurium. Vol. 2. Washington D.C.: American Society for Microbiology, 1988; 1625-48.

40. Selander RK, Korhonen TK, Väisänen-Rhen V, Williams PH, Pattison PE, Caugant DA. Genetic relationship and clonal structure of strains of Escherichia coli causing neonatal septicemia and meningitis. Infect Immun 1986; 52: 213-22.

41. Boyer HW, Roulland-Dussoix D. A complementation analysis of the restriction and modification of DNA in Escherichia coli. J Mol Biol 1969; 41: 459-72.

42. Birnboim HC, Doly J. A rapid alkaline extraction procedure for screening recombinant plasmid DNA. Nucleic Acids Res 1979; 7: 1513-22.

43. Maniatis T, Fritsch EF, Sambrook S. Molecular cloning: a laboratory manual. Cold Spring Harbor: Cold Spring Harbor Laboratory Press, 1982.

44. Thuring RWF, Sanders JP, Borst B. A freeze-squeeze method for recovering long DNA from agarose gels. Anal Biochem 1978; 66: 213-20.

45. Feinberg AP, Vogelstein B. A technique for radiolabeling DNA restriction endonuclease fragments to high specifity. Anal Biochem 1983; 132: 6-13.

46. Klemm $P$, Christiansen $G$. Three fim genes required for the regulation of length and mediation of adhesion of Escherichia coli type 1 fimbriae. Mol Gen Genet 1987; 208: 439-45.

47. Noegel A, Rdest U, Goebel W. Determination of the functions of hemolysin plasmid pHly 152 of Escherichia coli. J Bacteriol 1981; 145: 233-47.

48. Southern EM. Detection of specific sequences among DNA-fragments separated by gel electrophoresis. J Mol Biol 1975; 98: 503-17. 